\title{
UPDATE OF THE EUROTOP MANUAL: NEW INSIGHTS ON WAVE OVERTOPPING
}

\author{
Jentsje van der Meer ${ }^{1}$ William Allsop ${ }^{2}$, Tom Bruce ${ }^{3}$, Julien De Rouck ${ }^{4}$, Tim Pullen ${ }^{5}$, Holger \\ Schüttrumpf ${ }^{6}$, Peter Troch ${ }^{7}$ and Barbara Zanuttigh ${ }^{8}$
}

\begin{abstract}
Quite some new insights on wave overtopping were achieved since the first submission of the EurOtop Manual in 2007 which have now resulted in a second edition of this Manual. A major improvement has been made on the understanding of wave by wave overtopping and tolerable wave overtopping that is connected to it. Many videos are available on the overtopping website that show all kind of overtopping discharges and volumes and may give guidance for the user of the Manual. The EurOtop Neural Network and the EurOtop database are improved and extended versions of the earlier NN and CLASH database. New insights and prediction formulae have been developed for very low freeboards; for very steep slopes up to vertical walls; for run-up on steep slopes; for overtopping on storm walls on a promenade; and for overtopping on vertical walls, where overtopping has been divided in situations with and without an influencing foreshore and where the first situation may be divided in non-impulsive and impulsive overtopping.
\end{abstract}

Keywords: wave overtopping, wave run-up, tolerable overtopping, overtopping volumes, manual

\section{INTRODUCTION}

The EurOtop (2007), Manual on wave overtopping, has been a great success since its submission. It has been and is used in many designs all over the world of coastal structures. Quite some new insights on wave overtopping were achieved since the first submission of the Manual. This initiated the writing of a second editeion by the original author team, including a number of new co-authors, EurOtop (2016). The new insights on wave overtopping, with scientific background and guidance for application, are the subject of this paper.

\section{TOLERABLE WAVE OVERTOPPING}

\section{Influence of wave height on tolerable wave overtopping}

The first EurOtop Manual (2007) gave four tables with estimated tolerable overtopping for specific hazards, like limits for pedestrians, vehicles, property behind the defence and structural damage to the crest and rear slope. These tables have been used many times in assessing the crest level for design purposes. One of the main insights developed since EurOtop (2007) is that tolerable overtopping depends very strongly on the peak volume, and hence on the wave height that causes the overtopping. For a given mean overtopping discharge, small waves only give small overtopping volumes, whereas large waves may give many cubic metres of overtopping water in one wave. In that sense a mean tolerable overtopping discharge should be coupled to a wave height causing that discharge (simpler than assessing the maximum volume itself, but see below). This important insight changes the limits for tolerable overtopping.

Research in recent years has focussed on the description of distributions of overtopping wave volumes over the crest, see Chapters 5, 6 and 7 of EurOtop (2016). In this way the maximum overtopping volume $\mathrm{V}_{\max }$ may now be calculated for some structures of simple geometry with reasonable accuracy. Of course it will not only be the maximum volume that may cause damage, but all overtopping volumes that are close to this maximum overtopping volume. Nevertheless, $\mathrm{V}_{\max }$ is a good parameter to describe how severe the wave overtopping is or can be.

The statistical distribution of overtopping wave volumes depends on structure type, incident wave conditions (wave height and wave period), freeboard, duration of wave overtopping and the mean

\footnotetext{
${ }^{1}$ Van der Meer Consulting, P.O. Box 11, 8490AA, Akkrum, Netherlands; UNESCO-IHE, Delft, Netherlands

${ }^{2}$ HR Wallingford, Howbery Park, Wallingford, Oxfordshire, OX10 8BA, United Kingdom

${ }^{3}$ University of Edinburgh, School of Engineering, King's Buildings, Edinburgh, EH11 1RW, Scotland, UK

${ }^{4}$ Ghent University, Technologiepark 904, B-9052 Zwijnaarde, Ghent, Belgium

${ }^{5}$ HR Wallingford, Howbery Park, Wallingford, Oxfordshire, OX10 8BA, United Kingdom

${ }^{6}$ RWTH Aachen University, Institute of Hydraulic Engineering and Water Resources Management, Mies-van-der-Rohe Str. 17, 52074, Aachen, Germany

${ }^{7}$ Ghent University, Technologiepark 904, B-9052 Zwijnaarde, Ghent, Belgium

${ }^{8}$ DICAM, University of Bologna, V.le Risorgimento 2, Bologna, BO, 40136, Italy
} 
overtopping discharge. If wave conditions and resulting mean overtopping discharges are similar for various structures like sloping seawalls and embankments, rubble mound breakwaters and vertical structures, the distribution of overtopping wave volumes will also be of the same order. The main influence of the wave height can be illustrated by just choosing one structure type, one wave steepness and one duration of the sea state. A sloping smooth structure was chosen with a wave steepness of $\mathrm{s}_{\mathrm{op}}=0.04$ (fairly steep wind waves) and a storm duration of one hour. Choosing a lower wave steepness will result in fewer but larger overtopping volumes. A longer storm duration will just increase the maximum overtopping volume a little.

Examples of statistical distributions of overtopping wave volumes will be given here, based on equations given in Chapters 5, 6 and 7 of EurOtop (2016). Calculations were made for wave heights of $\mathrm{H}_{\mathrm{m} 0}=1 \mathrm{~m} ; 2 \mathrm{~m} ; 3 \mathrm{~m}$ and $5 \mathrm{~m}$ and for a mean wave overtopping discharges of $5 \mathrm{l} / \mathrm{s}$ per $\mathrm{m}$. It should be noted that if distributions of overtopping wave volumes are based on less than 5-10 waves, the distribution will be quite uncertain and calculated overtopping volumes will not be accurate.

The wave heights above distinguish "roughly" between three situations that might occur in practice:

- $\quad \mathrm{H}_{\mathrm{m} 0} \leq 1 \mathrm{~m} \quad$ Rivers, wide canals and small lakes. Often embankments covered with grass.

- $\mathrm{H}_{\mathrm{m} 0}=1-3 \mathrm{~m}$ Sheltered seashores and large lakes. Embankments, seawalls with the wave attack zone protected by rock, concrete units or block revetments. Grass covered crest or protected promenades / boulevard.

- $\mathrm{H}_{\mathrm{m} 0} \geq 3-5 \mathrm{~m}$ High waves and large water depths (>10 m) near the structure. Breakwaters, seawalls at land reclamations.

Figure 1 shows the distributions of overtopping wave volumes for $\mathrm{H}_{\mathrm{m} 0}=1 \mathrm{~m} ; 2 \mathrm{~m} ; 3 \mathrm{~m}$ and $5 \mathrm{~m}$, respectively. The graph gives the maximum overtopping wave volume, $\mathrm{V}_{\max }$, as well as the number of overtopping waves. It also shows that it is mainly the wave height that has a large influence on the maximum overtopping volume. The wave height of $\mathrm{H}_{\mathrm{m} 0}=1 \mathrm{~m}$ gives almost 250 overtopping waves, but the maximum overtopping volume is just $500 \mathrm{l}$ per $\mathrm{m}$. For a wave height of $\mathrm{H}_{\mathrm{m} 0}=5 \mathrm{~m}$, only 14 waves overtop during one hour, but the maximum overtopping volumes exceeds $5000 \mathrm{l}$ per $\mathrm{m}$. This is about ten times more than for a wave height of $1 \mathrm{~m}$.

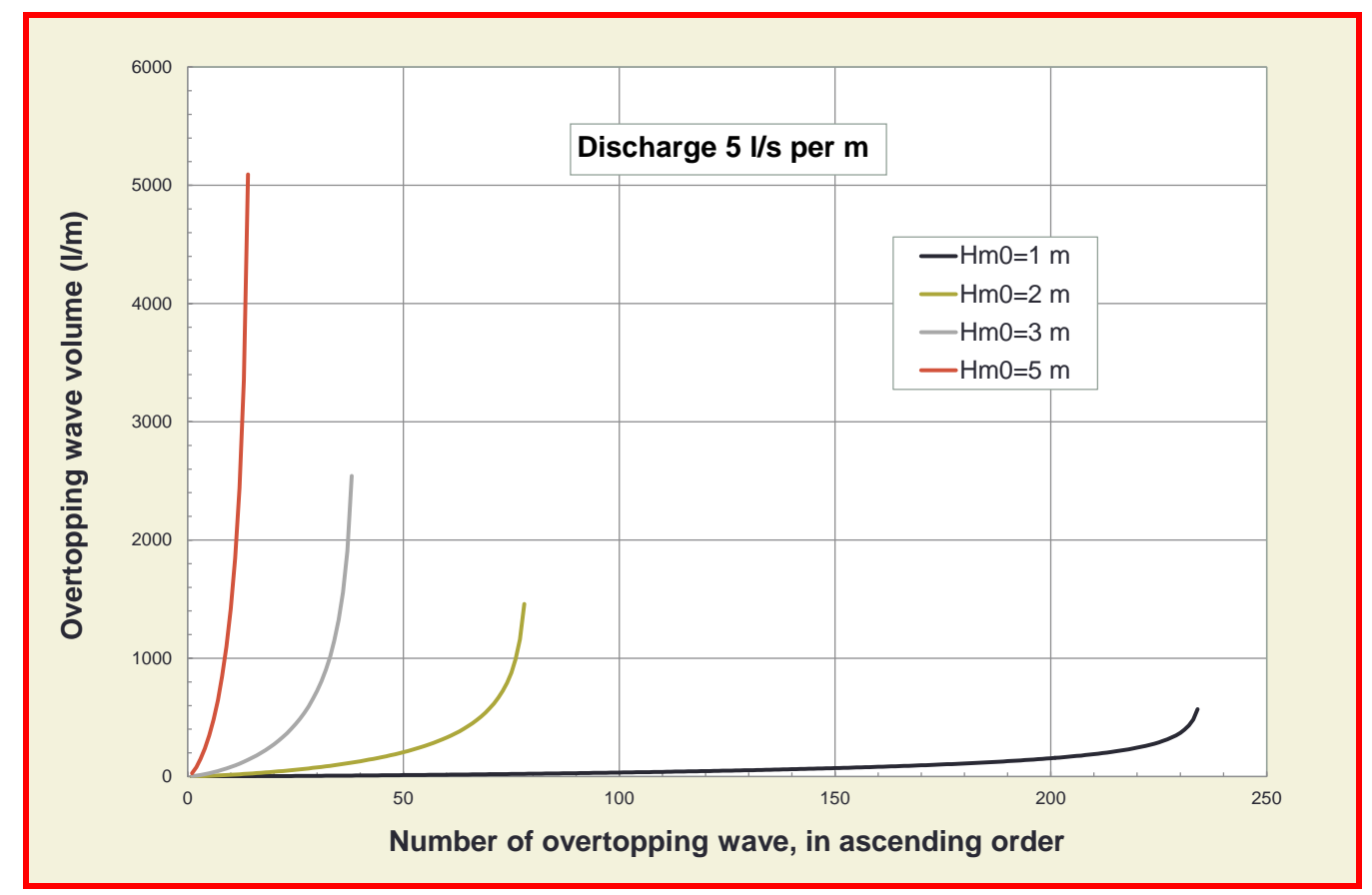

Figure 1. Distribution of overtopping wave volumes for a discharge of $5 \mathrm{l} / \mathrm{s}$ per $\mathrm{m}$ and for various wave heights; wave steepness $S_{o p}=0.04$ and duration of sea state is one hour. 
It is likely that most (perhaps all) damage close to the defence is caused by the largest overtopping volumes, so tolerable limits should be based on these volumes and not only on tolerable mean discharges. A maximum tolerable overtopping volume, however, may be given by different wave heights combined with different mean discharges. If for example $\mathrm{V}_{\max }$ were to be limited to 2000-3000 l per $\mathrm{m}$, then $\mathrm{H}_{\mathrm{m} 0}=1 \mathrm{~m}$ may exceed a mean discharge of $\mathrm{q}=75 \mathrm{l} / \mathrm{s}$ per $\mathrm{m}$. A wave condition of $\mathrm{H}_{\mathrm{m} 0}=3 \mathrm{~m}$ may then not exceed $\mathrm{q}=10 \mathrm{l} / \mathrm{s}$ per $\mathrm{m}$; and a wave height of $\mathrm{H}_{\mathrm{m} 0}=5 \mathrm{~m}$ not exceed $\mathrm{q}=1 \mathrm{l} / \mathrm{s}$ per $\mathrm{m}$.

\section{Simulated wave overtopping on videos}

For many people an overtopping discharge is simply a figure without any physical feeling. This is logic as real overtopping is random in time and with different overtopping wave volumes. Since the testing with the wave overtopping simulator at real dikes (see Section 4.8 of EurOtop 2016) it is possible to simulate mean overtopping discharges for all kind of wave conditions. And every year since 2007 dikes in the Netherlands or Belgium, US and Vietnam have been tested for a variety of wave and overtopping conditions. The main objective was to test the strength of grass cover, under laying soil and transitions against wave overtopping and to come to improved guidelines.

But such a wave overtopping simulator can also be used to demonstrate how wave overtopping looks like for a certain condition. Infram in the Netherlands performed the logistic operation of testing with the wave overtopping simulator. After completion of the testing in 2014 Infram has installed the wave overtopping simulator on the crest of a dike and simulated a large number of overtopping discharges, which were taken on video. Elaborated videos have been placed on the overtopping website, www.overtopping-manual.com.

The videos have been prepared in the following way. In total 18 conditions were prepared, being for mean overtopping discharges of $1 ; 5 ; 10 ; 30 ; 50$; and $75 \mathrm{l} / \mathrm{s}$ per $\mathrm{m}$ and for wave heights of $\mathrm{H}_{\mathrm{m} 0}=1$; 2; and $3 \mathrm{~m}$. Each distribution of overtopping wave volumes was calculated for a smooth gentle 1:3 slope, a wave steepness of $\mathrm{s}_{\mathrm{op}}=0.04$ and a duration of one hour. Example distributions for an overtopping discharge of $5 \mathrm{l} / \mathrm{s}$ per $\mathrm{m}$ and for various wave heights were discussed in the previous section. The simulation of the overtopping events by the wave overtopping simulator occurred by choosing randomly volumes from the distribution. Then the first three minutes of the steering file of one hour was taken, simulated and the test was recorded on video. It was judged that a video of three minutes would be long enough to give a good impression of a certain overtopping discharge, coupled to a certain wave height.

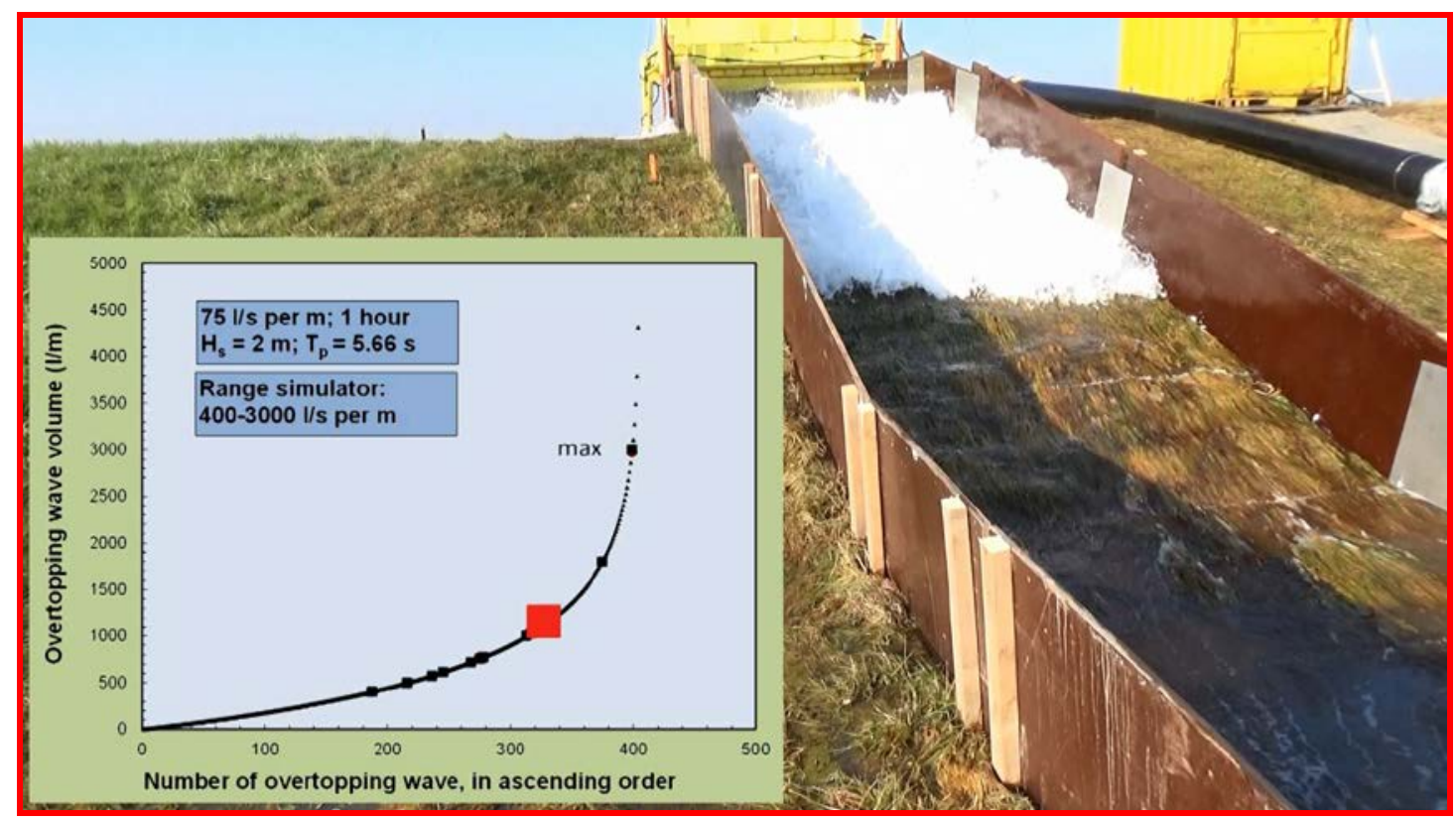

Figure 2. Snapshot of a three-minute video showing the overtopping wave volume from the wave overtopping simulator as well the size in the graph (red square) 
The mean overtopping discharge for a wave height of $\mathrm{H}_{\mathrm{m} 0}=5 \mathrm{~m}$ could not be simulated as for a discharge of $5 \mathrm{l}$ /s per $\mathrm{m}$ the maximum capacity of the wave overtopping simulator of $3000 \mathrm{l}$ per $\mathrm{m}$ was already exceeded. Therefore, simulations and videos were limited to a wave height of $\mathrm{H}_{\mathrm{m} 0}=3 \mathrm{~m}$.

Videos were recorded from two locations, one at the down-slope looking upwards and one next to the wave overtopping simulator and looking downwards. Videos were processed in a way that they also show the distribution of overtopping wave volumes and the volume illustrated on the video. Figure 2 gives a snapshot of a video taken from the downslope. The video shows a mean discharge of $50 \mathrm{l} / \mathrm{s}$ per $\mathrm{m}$ for a wave height of $2 \mathrm{~m}$. The actual overtopping wave volume shown on the video is marked by a red square and amounts about $700 \mathrm{l}$ per $\mathrm{m}$. The video gives an impression of how many waves overtop in three minutes, what overtopping wave volumes they reach and what the velocity and flow thickness is over the slope.

Besides taking three-minute videos also specific overtopping wave volumes were captured, from $100 \mathrm{l}$ per m up to $3000 \mathrm{l}$ per $\mathrm{m}$. In summary the following videos were prepared for the website:

- $\quad$ Three-minute videos looking up-slope, with the distribution of overtopping wave volumes

- $\quad$ Three-minute videos from the crest of the dike looking downwards

For conditions: $\quad \mathrm{H}_{\mathrm{m} 0}=1 \mathrm{~m} ; 2 \mathrm{~m}$ and $3 \mathrm{~m}$

and: $\quad \mathrm{q}=1 ; 5 ; 10 ; 30 ; 50$ and $75 \mathrm{l} / \mathrm{s}$ per $\mathrm{m}$ :

- Individual overtopping wave volumes of $100 ; 150 ; 200 ; 250 ; 300 ; 400 ; 500 ; 600 ; 700 ; 800$; $1000 ; 1200 ; 1400 ; 1600 ; 1800 ; 2000 ; 2250 ; 2500 ; 2750$ and $3000 \mathrm{l}$ per $\mathrm{m}$.

The objective of making the videos available is that people interested in wave overtopping may get a clear view of a given mean overtopping discharge. Moreover, the videos can be used to make a judgement on whether these overtopping discharges can be tolerated, depending on the actual situation. It should be noted that wave heights larger than $3 \mathrm{~m}$ always give large overtopping wave volumes if the mean discharge exceeds 1-5 l/s per m. These volumes exceed the capacity of the wave overtopping simulator and videos for these circumstances could not be made.

\section{Tolerable overtopping summarised in Tables}

Sea defences and breakwaters should withstand severe wave attack and are often armoured on the seaward side with rock, concrete units, or block revetments. River dikes and small reservoir dams are often only protected by a grass cover, but wave heights in these situations are limited. Waves that overtop the structure may attack the crest and rear side of the structure. Such a rear side could be a grass covered slope (dike), but might also be a promenade or other higher ground. A breakwater with limited wave overtopping may have a rear face protected by smaller material than on the seaward side. In all such cases, however, the tolerable wave overtopping should not significantly damage the crest or rear side, regardless of structure type. Suggestions for limits for wave overtopping for structural design are given in Table 1

\begin{tabular}{|l|c|c|}
\hline \multicolumn{1}{|c|}{ Table 1. Limits for wave overtopping for structural design of breakwaters, seawalls, dikes and dams } \\
\hline \multicolumn{1}{|c|}{ Hazard type and reason } & $\begin{array}{c}\text { Mean discharge } \\
\text { q (I/s per } \mathrm{m} \text { ) }\end{array}$ & $\begin{array}{c}\text { Max volume } \\
\mathbf{V}_{\text {max }} \text { (I per } \mathrm{m} \text { ) }\end{array}$ \\
\hline Rubble mound breakwaters; $\mathrm{H}_{\mathrm{m} 0}>5 \mathrm{~m}$; no damage & 1 & $2,000-3,000$ \\
\hline $\begin{array}{l}\text { Rubble mound breakwaters; } \mathrm{H}_{\mathrm{m} 0}>5 \mathrm{~m} \text {; rear side designed for } \\
\text { wave overtopping }\end{array}$ & $5-10$ & $10,000-20,000$ \\
\hline $\begin{array}{l}\text { Grass covered crest and landward slope; maintained and } \\
\text { closed grass cover; } \mathrm{H}_{\mathrm{m} 0}=1-3 \mathrm{~m}\end{array}$ & 5 & $2,000-3,000$ \\
\hline $\begin{array}{l}\text { Grass covered crest and landward slope; not maintained } \\
\text { grass cover, open spots, moss, bare patches; } \mathrm{H}_{\mathrm{m} 0}=0.5-3 \mathrm{~m}\end{array}$ & 0.1 & 500 \\
\hline Grass covered crest and landward slope; $\mathrm{H}_{\mathrm{m} 0}<1 \mathrm{~m}$ & $5-10$ & 500 \\
\hline Grass covered crest and landward slope; $\mathrm{H}_{\mathrm{m} 0}<0.3 \mathrm{~m}$ & No limit & No limit \\
\hline
\end{tabular}


Wave overtopping over a breakwater or sea defence structure may hit anything behind the structure crest. The level of tolerable overtopping for property and operation will be very site and structure specific. A few general examples will be given in this here, for promenades / boulevards, (temporary) storm walls, buildings and property and ships / yachts moored behind a breakwater. It is useful to recall that large incident wave heights may lead to large overtopping volumes, even if the mean overtopping discharge is quite small. And if a given overtopping limit is exceeded, it may lead to significantly larger overtopping volumes, perhaps destroying the property. Table 2 suggests limits for wave overtopping for property behind the defence.

\begin{tabular}{|l|c|c|}
\hline \multicolumn{2}{|c|}{ Table 2. General limits for overtopping for property behind the defence } \\
\hline \multicolumn{1}{|c|}{ Hazard type and reason } & $\begin{array}{c}\text { Mean discharge } \\
\text { q (I/s per } \mathrm{m} \text { ) }\end{array}$ & $\begin{array}{c}\text { Max volume } \\
\mathbf{V}_{\max } \text { (I per } \mathbf{~} \text { ) }\end{array}$ \\
\hline Significant damage or sinking of larger yachts; $\mathrm{H}_{\mathrm{m} 0}>5 \mathrm{~m}$ & $>10$ & $>5,000-30,000$ \\
\hline Significant damage or sinking of larger yachts; $\mathrm{H}_{\mathrm{m} 0}=3-5 \mathrm{~m}$ & $>20$ & $>5,000-30,000$ \\
\hline $\begin{array}{l}\text { Sinking small boats set 5-10 } \mathrm{m} \text { from wall; } \mathrm{H}_{\mathrm{m} 0}=3-5 \mathrm{~m} \\
\text { Damage to larger yachts }\end{array}$ & $>5$ & $>3,000-5,000$ \\
\hline Safe for larger yachts; $\mathrm{H}_{\mathrm{m} 0}>5 \mathrm{~m}$ & $<5$ & $<5,000$ \\
\hline Safe for smaller boats set 5-10 $\mathrm{m}$ from wall; $\mathrm{H}_{\mathrm{m} 0}=3-5 \mathrm{~m}$ & $<1$ & $<2,000$ \\
\hline Building structure elements; $\mathrm{H}_{\mathrm{m} 0}=1-3 \mathrm{~m}$ & $\leq 1$ & $<1,000$ \\
\hline Damage to equipment set back 5-10m & $\leq 1$ & $<1,000$ \\
\hline
\end{tabular}

It is in people's nature to watch violent wave action and overtopping. Some people may take risks, perhaps of injury or even of being drowned. To some extent owners / operators of coastal facilities can never avoid this. At some sites, public access may however be restricted when severe storms are forecast, but in others this may not be possible. For those sites, people should be warned of potential hazards from wave overtopping. A more focussed 'duty of care' will apply to staff who have a task to inspect and monitor the condition of sea defences during a storm surge.

Breakwaters may be particularly dangerous in storms where people can be washed off. In some instances an operating authority may be able to exclude access, but at others the public may still be able to access under severe wave conditions, even when such overtopping could be dangerous for people. Some coastal locations use seawalls and breakwaters for recreation such as the breakwater at Oostende, Belgium, Figure 3. Both in summer and winter, the breakwater allows access to people, indeed that is one of its functions. The crest is wide, has many places to sit, and is illuminated at night.

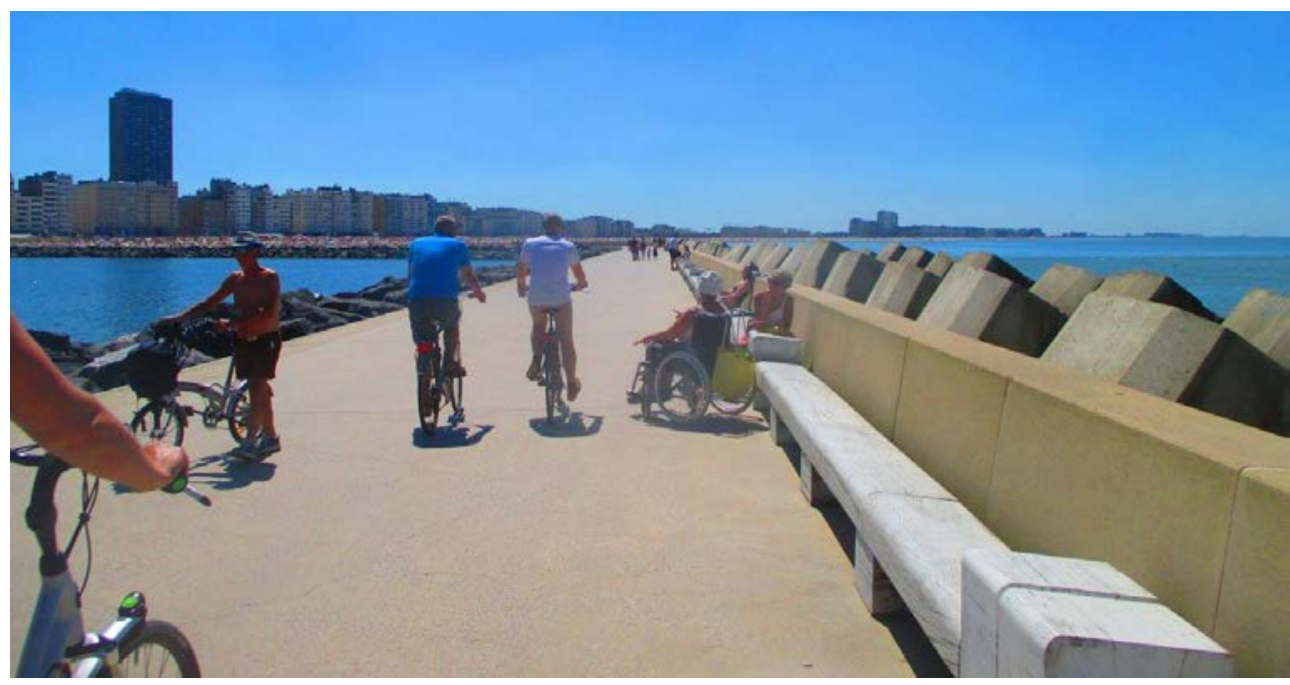

Figure 3. New breakwater at Oostende, Belgium, with a main function of access for people. 
Still the breakwater is not high, and with normal winter storms, overtopping may be expected at high tides. This overtopping will start for wave heights of $\mathrm{H}_{\mathrm{m} 0} \sim 2$ to $3 \mathrm{~m}$ at or near high tide. Following analysis of the videos described above, a maximum of $\sim 600 \mathrm{l}$ per $\mathrm{m}$ was taken for the maximum tolerable overtopping volume for people on the breakwater. The weather forecast system was used to calculate mean overtopping discharge and maximum overtopping wave volumes for predicted wave conditions and water levels. As soon as a condition is predicted to exceed the maximum overtopping volume of $600 \mathrm{l}$ per $\mathrm{m}$, the breakwater is closed at low water preceding the expected high tide overtopping. For wave heights exceeding $\mathrm{H}_{\mathrm{m} 0}=2 \mathrm{~m}$, the maximum overtopping volume, $\mathrm{V}_{\max }=600 \mathrm{l}$ per $\mathrm{m}$, at Oostende was calculated for overtopping discharges well below $1 \mathrm{l} / \mathrm{s}$ per $\mathrm{m}$. For $\mathrm{H}_{\mathrm{m} 0}=3 \mathrm{~m}$ the tolerable mean discharge was calculated at $\mathrm{q}<0.3 \mathrm{l} / \mathrm{s}$ per $\mathrm{m}$.

Tolerable overtopping discharges and overtopping wave volumes for people and vehicles are summarised in Table 3.

\begin{tabular}{|c|c|c|}
\hline \multicolumn{3}{|c|}{ Table 3. Limits for overtopping for people and vehicles } \\
\hline Hazard type and reason & $\begin{array}{l}\text { Mean discharge } \\
\text { q (I/s per m) }\end{array}$ & $\begin{array}{l}\text { Max volume } \\
\mathrm{V}_{\max }(\mathrm{I} \text { per } \mathrm{m})\end{array}$ \\
\hline $\begin{array}{l}\text { People at structures with possible violent overtopping, } \\
\text { mostly vertical structures }\end{array}$ & $\begin{array}{l}\text { No access for any } \\
\text { predicted overtopping }\end{array}$ & $\begin{array}{l}\text { No access for any } \\
\text { predicted overtopping }\end{array}$ \\
\hline \multicolumn{3}{|l|}{ People at seawall / dike crest. Clear view of the sea. } \\
\hline $\mathrm{H}_{\mathrm{m} 0}=3 \mathrm{~m}$ & 0.3 & 600 \\
\hline $\mathrm{H}_{\mathrm{m0}}=2 \mathrm{~m}$ & 1 & 600 \\
\hline $\mathrm{H}_{\mathrm{m} 0}=1 \mathrm{~m}$ & $10-20$ & 600 \\
\hline $\mathrm{H}_{\mathrm{mo}}<0.5 \mathrm{~m}$ & No limit & No limit \\
\hline \multicolumn{3}{|l|}{ Cars on seawall/dike crest, or railway close behind crest } \\
\hline $\mathrm{H}_{\mathrm{m} 0}=3 \mathrm{~m}$ & $<5$ & 2000 \\
\hline $\mathrm{H}_{\mathrm{m} 0}=2 \mathrm{~m}$ & $10-20$ & 2000 \\
\hline $\mathrm{H}_{\mathrm{mo}}=1 \mathrm{~m}$ & $<75$ & 2000 \\
\hline Highways and roads, fast traffic & $\begin{array}{l}\text { Close before debris in } \\
\text { spray becomes dangerous }\end{array}$ & $\begin{array}{l}\text { Close before debris in } \\
\text { spray becomes dangerous }\end{array}$ \\
\hline
\end{tabular}

\section{EUROTOP ARTIFICIAL NEURAL NETWORK AND DATABASE}

The CLASH database on wave overtopping tests and the resulting Artificial Neural Network for prediction of mean overtopping discharges for any type of coastal structure, are part of EurOtop (2007). The second edition will have a largely extended EurOtop database with in total more than 17,000 tests. The predicting Artificial Neural Network has been improved and optimised with respect to the CLASH one and will become the EurOtop ANN in the calculation tool of the manual. It will predict wave overtopping discharge as well as wave transmission and wave reflection. It is also possible that a second ANN becomes available to predict wave overtopping.

The new EurOtop ANN and database have been described by Zanuttigh et al (2016), part of this proceedings. Therefore one is referred to that reference, as well as to EurOtop (2016).

\section{NEW INSIGHTS AND PREDICTION FORMULAE}

\section{Approach of uncertainty}

EurOtop (2007) as well as EurOtop (2016) describe the reliability of the formulae often by taking one of the coefficients as a stochastic parameter and giving a standard deviation (assuming a normal distribution). The first EurOtop Manual (2007) gave then a deterministic and probabilistic approach of the prediction formulae, by giving two similar formulae with different coefficients in the formulae. The probabilistic approach used the mean value for the coefficient, where for the deterministic way about one standard deviation was added to the coefficient. The "deterministic way", therefore, included some safety as wave run-up and wave overtopping have a substantial uncertainty. 
Actually, the "deterministic design or safety assessment” approach in the first EurOtop Manual (2007) should be termed a semi-probabilistic approach as a partial safety factor of one standard deviation is used. The new EurOtop (2016) presents the following enhanced approaches:

- Mean value approach. Use the formula as given with the mean value of the stochastic parameter(s). This should be done to predict or compare with test data. In a graph also the $5 \%$-exceedance lines or $90 \%$-confidence band could be given to complete the comparison; this was called the probabilistic approach in EurOtop (2007);

- Design or assessment approach. This is an easy semi-probabilistic approach with a partial safety factor; this is the mean value approach above, but now with the inclusion of the uncertainty of the prediction. The stochastic parameter(s) become $(\mathrm{s}) \mu(\mathrm{m})+\sigma(\mathrm{m})$, where $\mathrm{m}$ is the model uncertainty; this was called the deterministic approach in EurOtop (2007);

- Probabilistic approach. Consider the stochastic parameter(s) with their given standard deviation and assuming a normal or log-normal distribution;

- The 5\%-exceedance lines, or $\mathbf{9 0 \% - c o n f i d e n c e ~ b a n d , ~ c a n ~ b e ~ c a l c u l a t e d ~ b y ~ u s i n g ~}$ $\mu(\mathrm{m}) \pm 1.64 \sigma(\mathrm{m})$ for the stochastic parameter(s).

In this paper, the formulae are given as a mean value approach. The formula(e) and $5 \%$-exceedance curves are given in a graphical way. Key coefficients are taken as stochastic variables, and uncertainty is then described by giving the standard deviation, $\sigma(\mathrm{m})$. The coefficient to be used in the formula for the design or assessment approach will also be given. An example of this approach is shown next for wave run-up and is followed throughout this paper. The probabilistic approach is not used in this paper.

The formula for the $2 \%$-wave run-up level is given by (assuming breaking waves only):

$$
\frac{R_{u 2 \%}}{H_{m 0}}=1.65 \cdot \gamma_{b} \cdot \gamma_{f} \cdot \gamma_{\beta} \cdot \xi_{m-1,0}
$$

The coefficient 1.65 can be considered as a stochastic variable with a mean value of $m=1.65$ and a standard deviation of $\sigma(\mathrm{m})=0.10$ and gives the mean value approach. For a design and assessment approach one should use the value of 1.75 instead of 1.65 .

\section{Wave run-up on very steep slopes up to vertical walls}

Dike slopes are often quite gentle, say gentler than 1:2.5. But seawalls and concrete structures may have steeper slopes. Steep slopes may give large breaker parameters exceeding the range for relatively gentle slopes, say $\xi_{\mathrm{m}-1,0}<3-4$. (Very) shallow foreshores may also give large breaker parameters and very large wave run-up, see EurOtop (2007) and EurOtop (2016) and Figure 4. But wave run-up for very steep slopes, without a shallow foreshore, will not be as high as the upper line in Figure 4.

Due to the work of Victor (2012) it is possible to give a good prediction of waver run-up for steep slopes up to vertical walls, at relatively deep water (no very shallow foreshore). This investigation focussed on wave overtopping on very steep slopes and prediction formulae will be given in the next section. Those formulae on wave overtopping on very steep slopes can be used to estimate the wave run-up level $\mathrm{R}_{\mathrm{u} 2 \%} / \mathrm{H}_{\mathrm{m} 0}$. For these calculations a wave height of $\mathrm{H}_{\mathrm{m} 0}=3 \mathrm{~m}$ was taken and it was assumed that an overtopping discharge of $1 \mathrm{l} / \mathrm{s}$ per $\mathrm{m}$ would be quite close to a run-up level of $2 \%$. The required crest level for an overtopping discharge of $1 \mathrm{l} / \mathrm{s}$ per $\mathrm{m}$ was then taken as $R_{\mathrm{u} 2 \%}$. Calculations were performed for various slope angles.

Figure 4 shows the equations for relatively gentle slopes and for the situation of (very) shallow foreshores, but it also shows the relative wave run-up (calculated as described above) for slopes of 1:2 and steeper, up to the limit of a vertical wall. Actually, in the zone of surging or non-breaking waves, say $\xi_{\mathrm{m}-1,0}>2$, the wave period or wave steepness has no influence anymore on wave run-up and each slope angle shows a horizontal line. The length of the line is given by the range of wave steepness that was applied: $s_{m 1,0}=0.01$ to 0.06 . The graph shows that a steeper slope gives smaller wave run-up. The relative wave run-up against a vertical wall will be $\mathrm{R}_{\mathrm{u} 2 \%} / \mathrm{H}_{\mathrm{m} 0}=1.8$. Figure 4 shows clearly the difference between a (very) shallow foreshore and steep slopes without significant wave breaking on a foreshore, but in both situations large breaker parameters will be found. For application of wave runup formulae one has to distinguish between the situation of no or limited wave breaking on a foreshore and (very) shallow foreshores. 


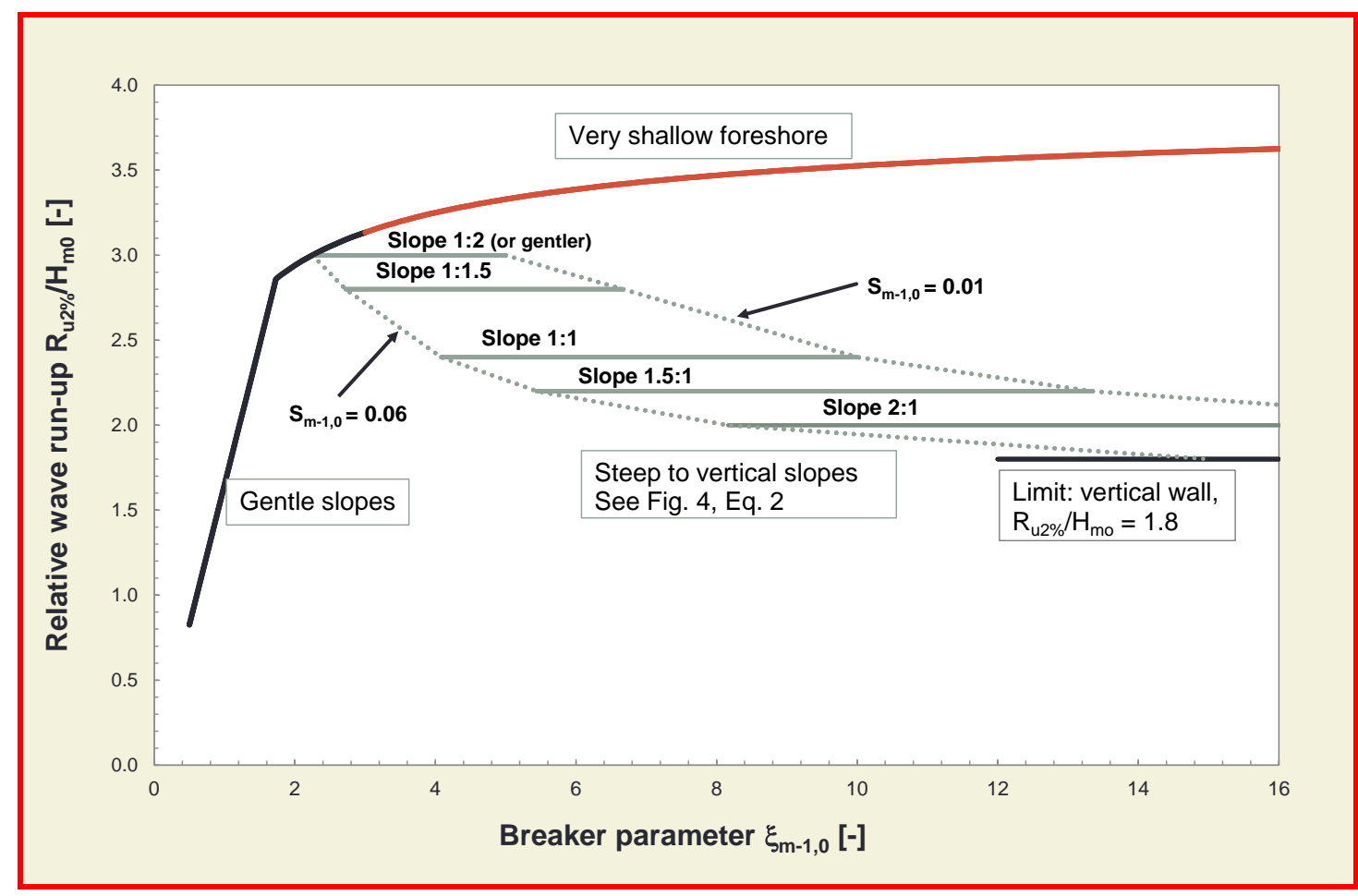

Figure 4. Wave run-up for (very) steep slopes compared to gentle slopes and situations with (very) shallow foreshores - mean value approach. Based on Victor (2010).

As steep slopes show no influence of wave steepness on wave run-up it is possible to give a prediction formula that is only based on the slope angle cota. Figure 4 shows the relative wave run up for steep slopes up to a vertical wall as a function of the slope angle and excluding the influence of a foreshore. The prediction is given by Equation 2.

$$
\frac{R_{u 2 \%}}{H_{m 0}}=0.8 \cot \alpha+1.6 \text { with a minimum of } 1.8 \text { and a maximum of } 3.0 \text { (2) }
$$

The question is: what happens for very steep slopes on very gentle foreshores? The deviation in Figure 4 for breaker parameters $\xi_{\mathrm{m}-1,0}>10$ is very large between the curve of (very) shallow foreshores and the curves for the very steep slopes. The difference can be up to a factor of 2 in run-up height, but research has yet to be conducted in this area. The upper curve in the graph was developed for 1:2 and 1:4 slopes at (very) shallow foreshores, but not for steeper slope angles. Still one can imagine that the "very shallow water effect" of infra gravity waves or surf beat may also increase wave run up for very steep slopes. Therefore, it is proposed to use this maximum for (very) shallow water (the upper line in Figure 4) always in the situation of shallow and very shallow water $\left(\mathrm{s}_{\mathrm{m}-1,0}<0.01\right)$, also for very steep slopes.

\section{Wave overtopping on sloping structures}

For sloping structures, overtopping at low and zero freeboard conditions has often been overlooked in physical model studies (perhaps due to the challenges of measurement of very large discharges) but they represent important situations, e.g. in analysis of performance of partiallyconstructed breakwaters, and of low-freeboard, lower-cost defences. It is clear that familiar, exponential-type formulae, work poorly in these regions as they over-estimate the overtopping discharge for very low freeboards.

Analysis has therefore been performed to bring together the conventional exponential formulae with the few reliable datasets including very low and zero freeboard. In doing so, Van der Meer and Bruce (2014) have revisited early Dutch work from the 1970s which offered a continuous prediction extending to zero freeboard. They proposed a curved line in an easy way, as the exponential function is a special case of the Weibull distribution, it is possible to go back to a Weibull-type function and use a fitted shape factor. 
The general formulae for the average overtopping discharge on a slope (dike, levee, embankment) are given by (mean value approach):

$$
\begin{aligned}
& \frac{q}{\sqrt{g \cdot H_{m 0}^{3}}}=\frac{0.023}{\sqrt{\tan \alpha}} \gamma_{b} \cdot \xi_{m-1,0} \cdot \exp \left[-\left(2.7 \frac{R_{c}}{\xi_{m-1,0} \cdot H_{m 0} \cdot \gamma_{b} \cdot \gamma_{f} \cdot \gamma_{\beta} \cdot \gamma_{v}}\right)^{1.3}\right] \\
& \text { with a maximum of } \frac{q}{\sqrt{g \cdot H_{m 0}^{3}}}=0.09 \cdot \exp \left[-\left(1.5 \frac{R_{c}}{H_{m 0} \cdot \gamma_{f} \cdot \gamma_{\beta} \cdot \gamma^{*}}\right)^{1.3}\right]
\end{aligned}
$$

Equations 3 and 4 show quite a number of influence factors: $\gamma_{b}$ is the influence factor for a berm, $\gamma_{\mathrm{f}}$ is the influence factor for roughness elements on a slope, $\gamma_{\beta}$ is the influence factor for oblique wave attack and $\gamma_{\mathrm{v}}$ is the influence factor for a wall at the end of a slope. All these influence factors have been described in depth in Section 5.4 of EurOtop (2016). Compared to EurOtop (2007), an influence factor $\gamma^{*}$ has been added for non-breaking waves (relatively steep slopes) for a storm wall on a slope or promenade. This influence factor $\gamma^{*}$ is a combined factor of all kind of geometrical influences and details have been given in Van Doorslaer et al. (2016), part of this proceedings, with an overall view further on in this paper.

Equation 3 is given in Figure 5 together with measured data for breaking waves from different model tests in small and large scale as well as in wave flumes and wave basins. Note that data in the graph are not all data that exist, as it is mainly the data used to come to the prediction formulae for EurOtop (2007). In addition to the mean prediction line in the graph, the 5\% lower and upper confidence limits have been plotted.

The reliability of Equation 3 is given by $\sigma(0.023)=0.003$ and $\sigma(2.7)=0.20$, and of Equation 4 by $\sigma(0.09)=0.0135$ and $\sigma(1.5)=0.15$. For a design or assessment approach it is strongly recommended to increase the average discharge by about one standard deviation.

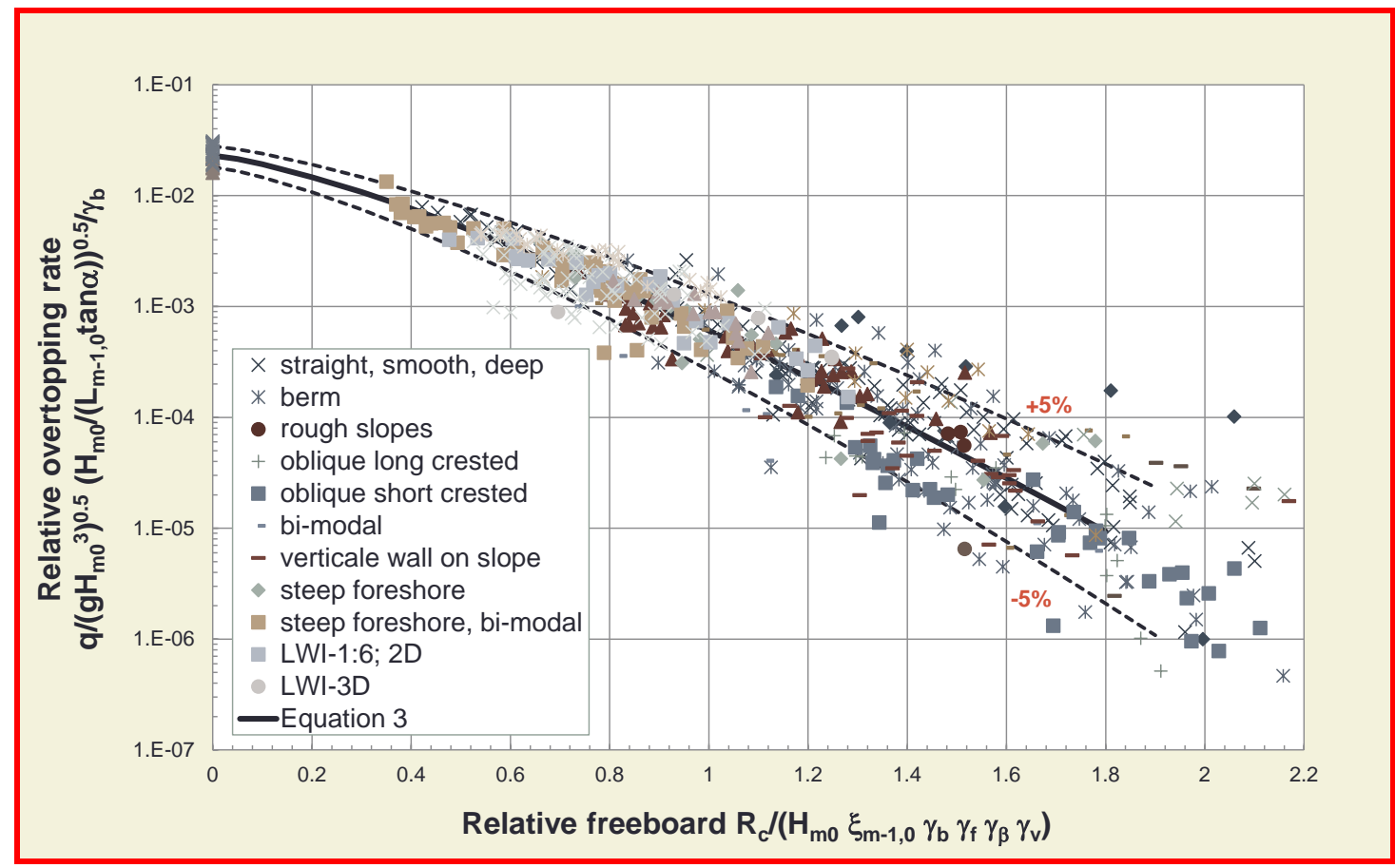

Figure 5. Wave overtopping data for breaking waves and overtopping Equation 3 with $5 \%$ under and upper exceedance limits (= 90\%-confidence band).

The new approach in EurOtop (2016) is given in Figure 6 and gives a prediction of the average discharge or mean value approach and of the design and assessment approach for non-breaking waves. It also gives the $90 \%$-confidence bands. 


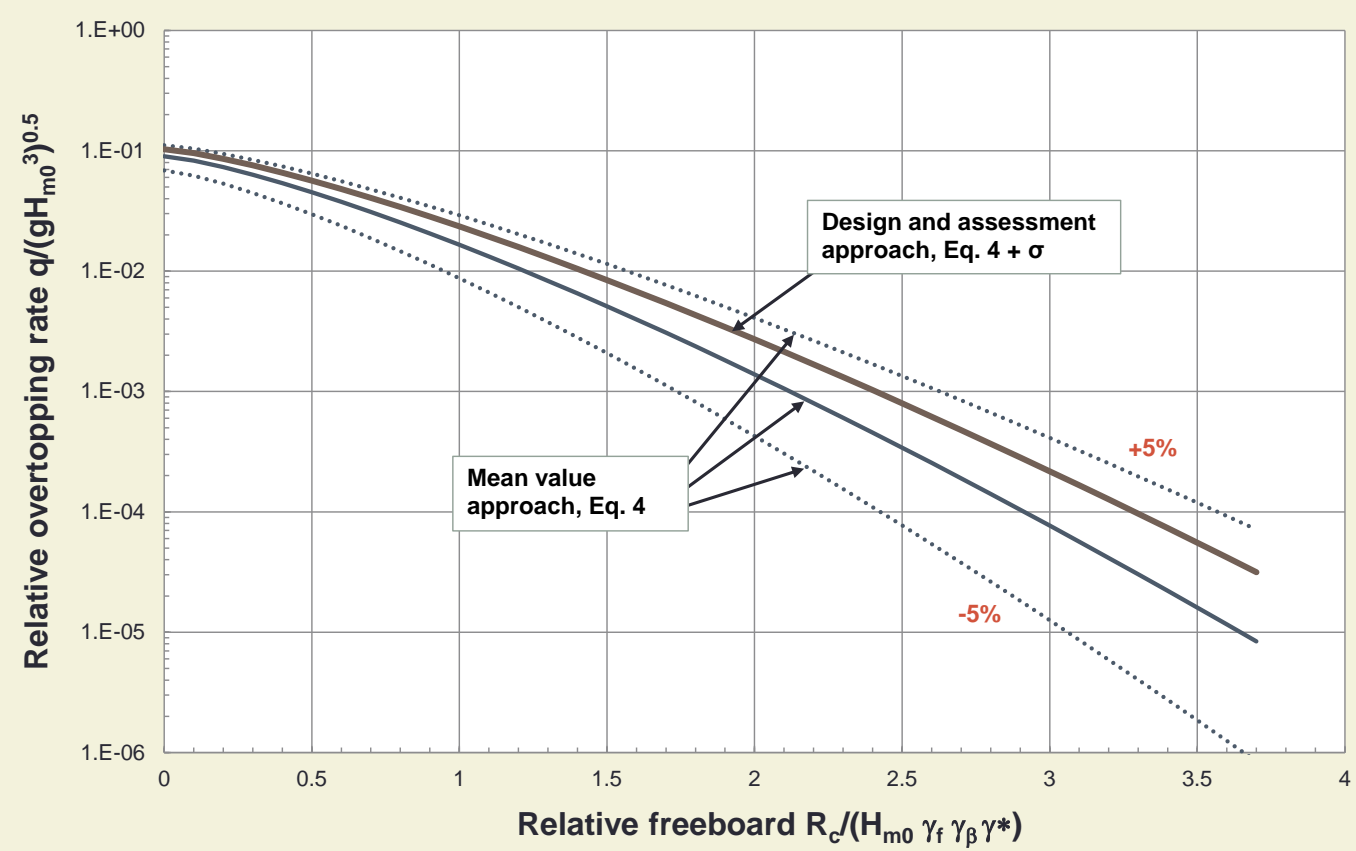

Figure 6. Wave overtopping for non-breaking waves - Comparison of formulae for mean value approach and design and assessment approach.

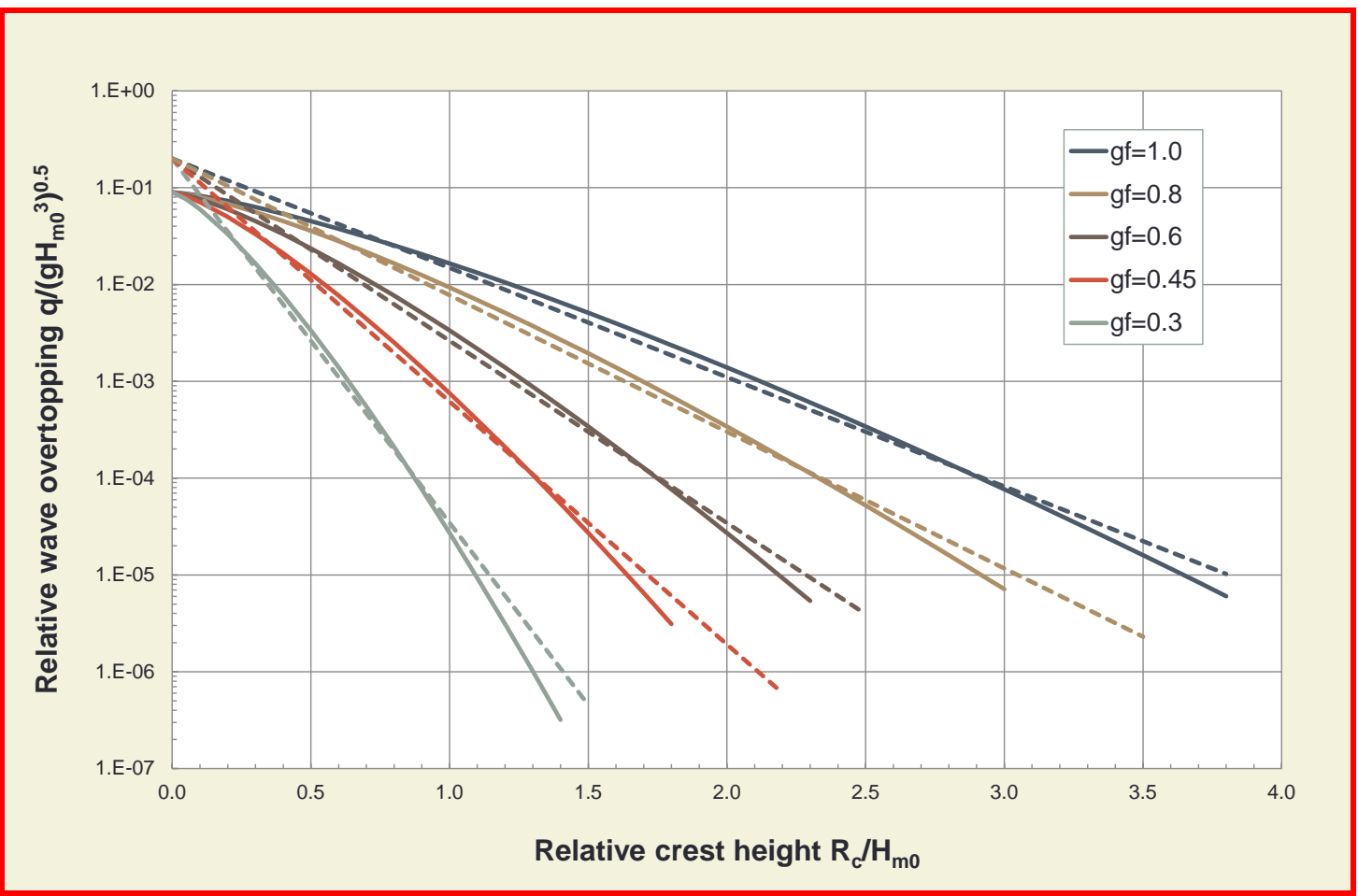

Figure 7. Comparison of Equation 5.11 with the original Equation 5.8 in EurOtop (2007), for various values of the influence factor for roughness.

EurOtop (2007) gave overtopping formulae according to a straight line on a log-linear graph. The application area was for $\mathrm{R}_{c} / \mathrm{H}_{\mathrm{m} 0}>0.5$, where the new equations in this second edition of the manual, like Equations 3 and 4, are valid for $\mathrm{R}_{\mathrm{c}} / \mathrm{H}_{\mathrm{m} 0}>0$. The new formulae widen the application area, but are very similar in the area with $\mathrm{R}_{\mathrm{c}} / \mathrm{H}_{\mathrm{m} 0}>0.5$. In order to compare the old EurOtop (2007) and the new 
formulae, including the effect of the roughness, Figure 7 was made for non-breaking waves (Equation 4 in this paper with Equation 5.8 in EurOtop (2007)). It is clear that the differences are very small, except in the area $\mathrm{R}_{\mathrm{c}} / \mathrm{H}_{\mathrm{m} 0}<0.5$.

Mathematically speaking, one would expect that due to the exponent $c=1.3$ in Equation 4, the effect of the influence factors would change, as the part within the exponential function becomes different for $\mathrm{c}=1$ (the old formula) and $\mathrm{c}=1.3$ (the new formula). This is indeed true for the same (large) value of $R_{c} / H_{m 0}$, but the effect of an influence factor is that the curve shifts to the left and remains in the same overtopping range. The actual difference between the old and new formulae is similar with and without an influence factor different from 1.0, see also Figure 7. The difference can be described as follows, depending on the actual value of $R_{c} / H_{m 0}$ : for breaking waves the new formulae may give up to $4 \%$ more overtopping discharge and up to $30 \%$ less than the old formulae. For nonbreaking waves it was up to $27 \%$ more and also about $30 \%$ less for the new formulae. Compared to the reliability of wave overtopping discharge prediction, which is estimated for a confidence band of $90 \%$ between a factor 2.5 and up to 20 or more (for very small overtopping) a deviation of up to $30 \%$ is small and insignificant.

\section{Steep slopes up to vertical walls}

Equations 3 and 4 show that smooth steep sloping structures with non-breaking wave conditions give largest (maximum) wave overtopping. But wave run-up in Figure 4 shows that run-up decreases for very steep (battered) and vertical walls. What happens if slopes become steeper than say 1:2 or 1:1.5? The two boundaries are known: the formula for steep smooth slopes with non-breaking waves (Equation 3) and a formula for vertical walls, see next Section on vertical walls, Equation 6. That section describes that for vertical walls a distinction has to be made for vertical walls at relatively deep water without an influencing foreshore and walls at the end of a influencing foreshore. Here we consider only vertical walls at relatively deep water, where waves are not (significantly) influenced by a sloping foreshore. The question can be answered quite easily as both situations have been based upon similar equations. For example Equation 4 for sloping structures has a fixed exponent $\mathrm{c}=1.3$, as well as Equation 4 in Section for vertical walls at relatively deep water, without sloping foreshore.

The connecting parameter is then the slope angle cot $\alpha$. Without any data one would probably choose a linear influence to combine the two equations to one general formula.

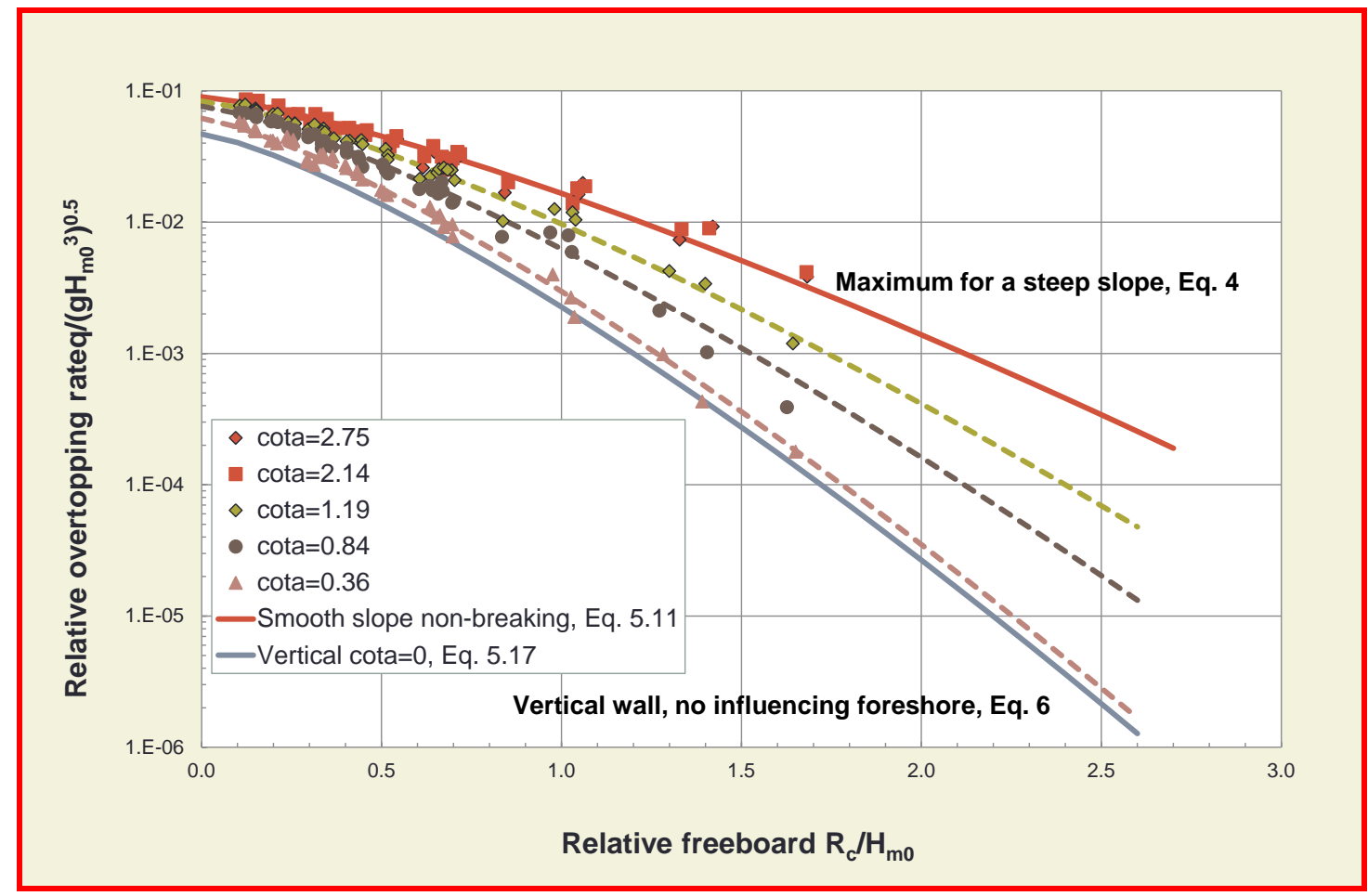

Figure 8. Wave overtopping data for very steep slopes up to vertical with Eq. 5 as overall formula. 
Very interesting data by Victor (2012) became available, however, with tests on steep and very steep smooth slopes with relatively low freeboards. Tested slope angles ranged from cot $\alpha=0.36$ (almost 3V:1H) to cot $\alpha=2.75$. Data of some selected slopes have been given in Figure 8, together with the two limiting equations, but also with an overall formula that combines these two equations with $\cot \alpha$ as the changing parameter. This formula is given in Equation 5 and is only applicable for smooth slopes. For this reason $\gamma_{f}$ has been omitted in Equation 5. The tests by Victor (2012) were performed by perpendicular wave attack only, therefore the inclusion of $\gamma_{\beta}$ (influence factor for oblique wave attack) in the equation is an assumption.

$$
\begin{aligned}
& \frac{q}{\sqrt{g \cdot H_{m 0}^{3}}}=a \cdot \exp \left[-\left(b \frac{R_{C}}{H_{m 0} \cdot \gamma_{\beta}}\right)^{1.3}\right] \text { (non-breaking waves) } \\
& \mathrm{a}=0.09-0.01(2-\cot \alpha) 2.1 \text { for } \cot \alpha<2 \text { and } \mathrm{a}=0.09 \text { for } \cot \alpha \geq 2 \\
& \mathrm{~b}=1.5+0.42(2-\cot \alpha) 1.5, \text { with a maximum of } \mathrm{b}=2.35 \text { and } \mathrm{b}=1.5 \text { for } \cot \alpha \geq 2
\end{aligned}
$$

\section{Storm walls on promenades}

A main improvement in EurOtop (2016) is based on Van Doorslaer et al. (2016), part of these procedings, and relates to a straight smooth seaward slope of 1:2 or 1:3 with a wave wall or storm wall on top of the slope or somewhere on a promenade, with or without bullnose. The general configuration of a promenade with storm wall is given in Figure 9.

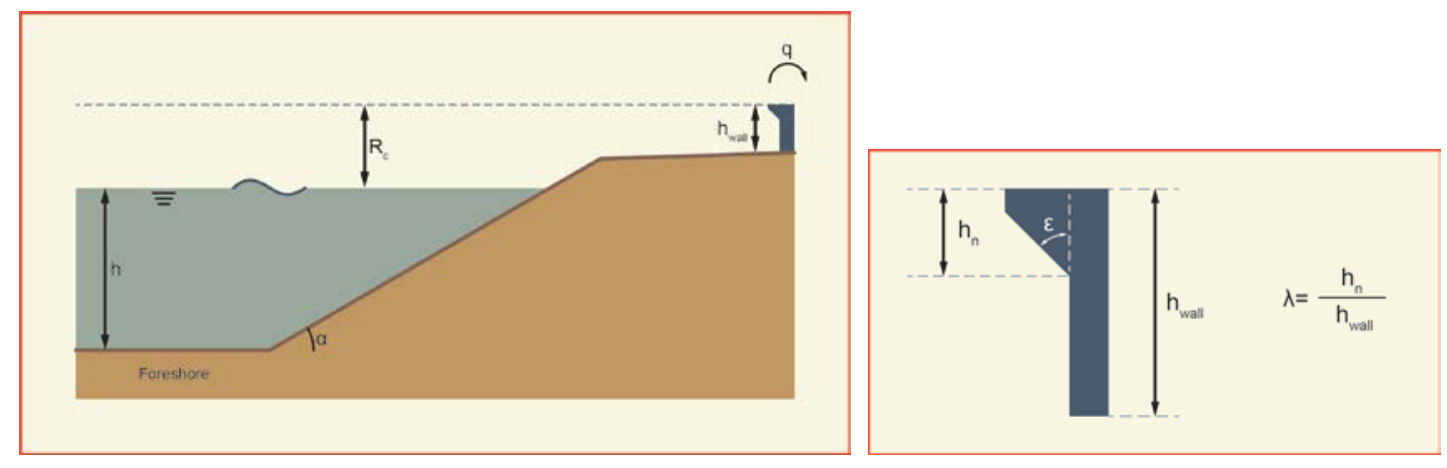

Figure 9. Configuration of a slope with a promenade and a storm wall with bullnose

In order to give an overall view and an impression of the possible effects of storm walls and a bullnose, Figure 10 and Figure 11 were produced. The first figure gives all test results with the trend line for a smooth straight 1:2 or 1:3 slope as reference. The $5 \%$ exceedance lines (or $90 \%$ confidence band) are based on the reliability given for Equation 4.

Figure 10 shows that a smooth slope gave always the largest wave overtopping and that any measure, such as a promenade, a storm wall, with or without a bullnose, reduces wave overtopping. The smallest influences are found for extending the top of the slope with a promenade only (no storm wall) and with a storm wall directly on the slope, without promenade or bullnose. Those data points are closest to the trend line for a smooth slope and mostly within the $90 \%$ confidence band. Most effective are a wall with bullnose on a slope or a wall with or without bullnose on a promenade. Those data points give often overtopping that is a factor of 10-100 smaller than for a smooth straight slope, with the same crest level.

If all the reduction factors have been applied that have been described in Van Doorslaer et al. (2016), it gives Figure 11. The test results have been analysed in great detail, leading to a graph with limited scatter around the main curve. Actually, the scatter for these specific tests is significantly smaller than for the overall Equation 4, which is given in the graph by the 5\% exceedance lines. Note that the graphs are for non-breaking waves only, as the tested seaward slopes of 1:2 and 1:3 always gave non-breaking waves and the actual slope was used to calculate the breaker parameter, $\xi_{\mathrm{m}-1,0}$. 
The range of application of a storm wall on a slope or promenade can be given as follows:

- the foot of the storm wall is above swl

- $\cot \alpha=2-3$ (this could also be an average slope)

- $\mathrm{s}_{\mathrm{m}-1,0}=0.01-0.05$

- $\xi_{\mathrm{m}-1,0}=2.2-4.8$ (based on the seaward slope only)

- $\mathrm{R}_{\mathrm{C}} / \mathrm{H}_{\mathrm{m} 0}>0.6$

- Promenade slope $1 \%$ and $2 \%$

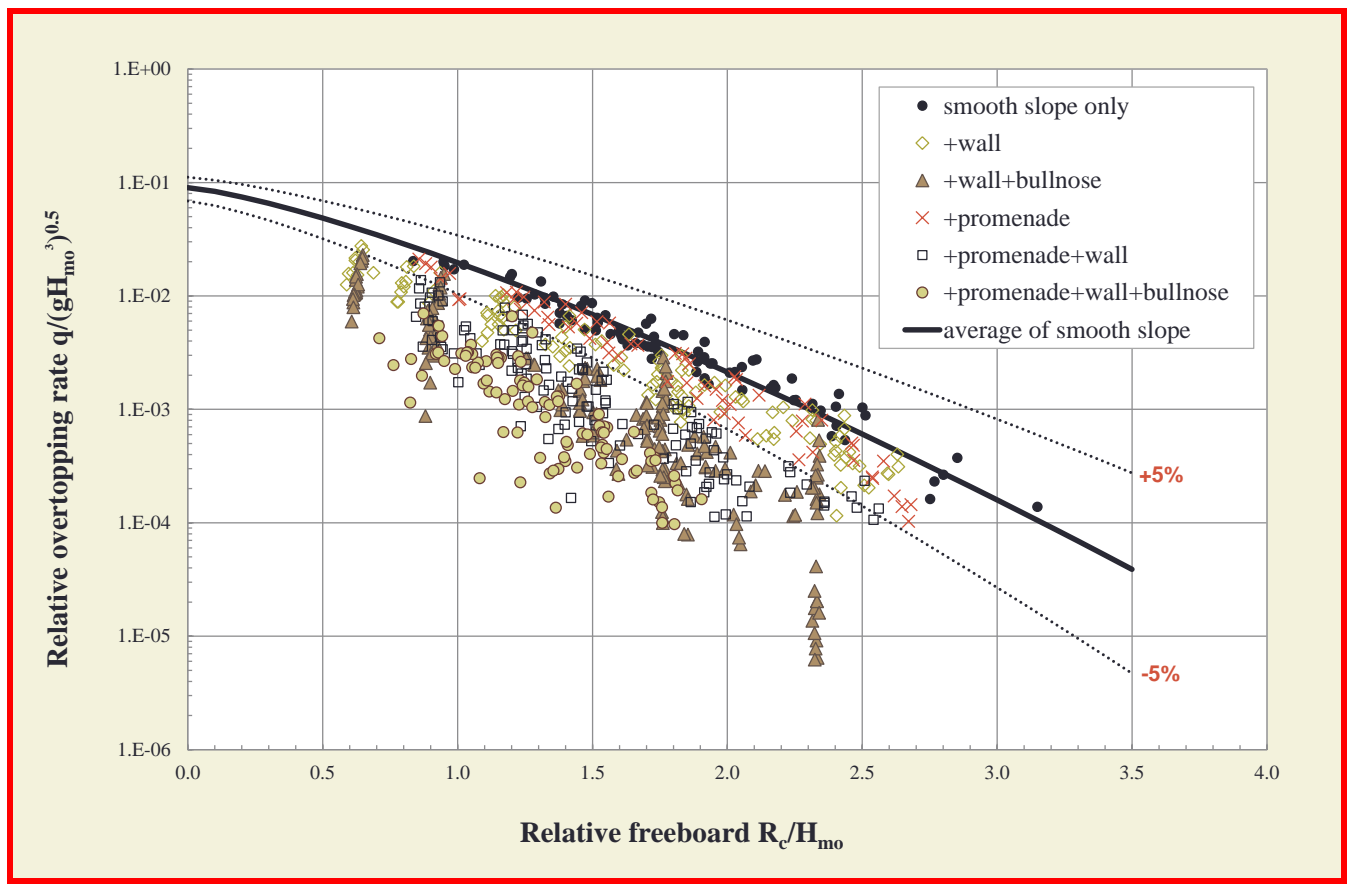

Figure 10. All test results of Van Doorslaer et al. (2016) on wave walls with or without bullnose, without applying all reduction factors.

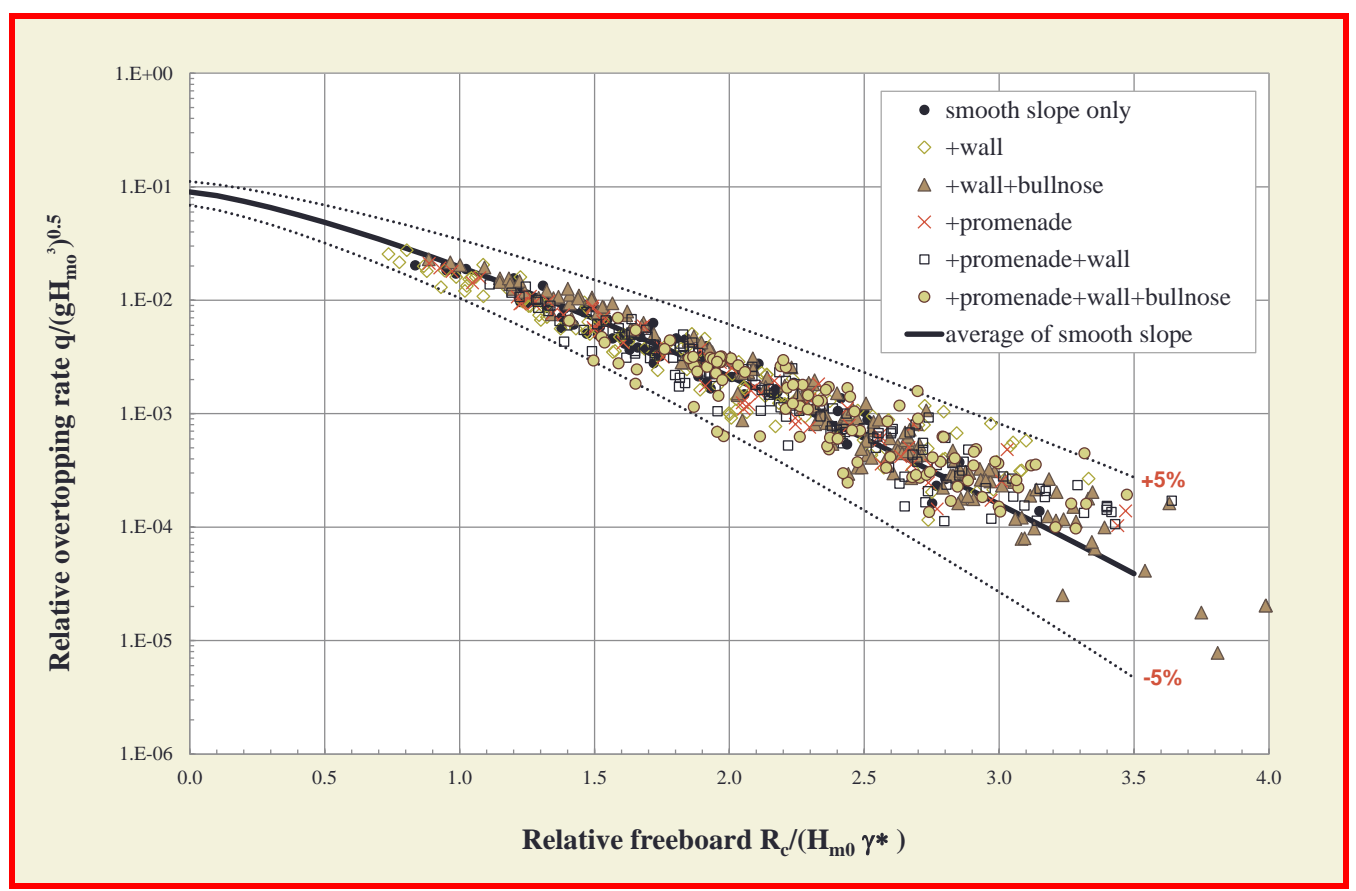

Figure 11. All test results of Van Doorslaer et al. (2016) on wave walls with or without bullnose, applying all reduction factors. 


\section{Vertical walls}

For plain vertical walls some initial insight into the way in which the methodology is divided-up between distinct settings can be gained from Figure 12. The figure shows the relative (nondimensional) overtopping discharge plotted against the relative freeboard. On this, three regimes can be identified:

1) The situation for a vertical wall where there is no influence of foreshore, e.g. for relative deep water. For a given relative freeboard, such a setting gives the lowest overtopping. The functional form of the overtopping is well-described by the same formulation as for sloping structures, viz a Weibull curve. For a large area, however, it is close to the well-known Franco et al. formula (1994).

2) The situation where there is influence of the foreshore, but no wave breaking onto the structure ("non-impulsive" overtopping only). Comparing these situations to (1), it is clear that these give higher overtopping. At lower freeboards, there is hardly difference, but can become quite large for higher freeboards. The overtopping under these situations is well-described by the familiar exponential function (a straight line on a log-linear graph) and more specifically by the Allsop et al. formula (1995).

3) The situation where some waves break at the structure, giving "impulsive" overtopping. For these conditions, the up-rushing water can reach very great heights, and significant overtopping can be expected up to very high relative freeboards, witnessed by the near-horizontal lines extending to the right of the figure. A power-law formulation is used to describe this situation, with the influence of relative depth and wave steepness accounted for in the formulae too (giving the family of curves seen in the figure).

The strategy for assessment of mean overtopping discharge follows a procedure. In order to arrive at the most appropriate prediction equation, the following questions may need to be answered:

- Is an influencing foreshore present in front of the structure?

- Is the structure a simple vertical or steep wall, or is there a significant mound present?

- Is the structure likely to experience impulsive (violent, wave-breaking) overtopping?

The first two questions lead to the predictions for a plane vertical wall, as shown in Figure 12 and are given as Equations .

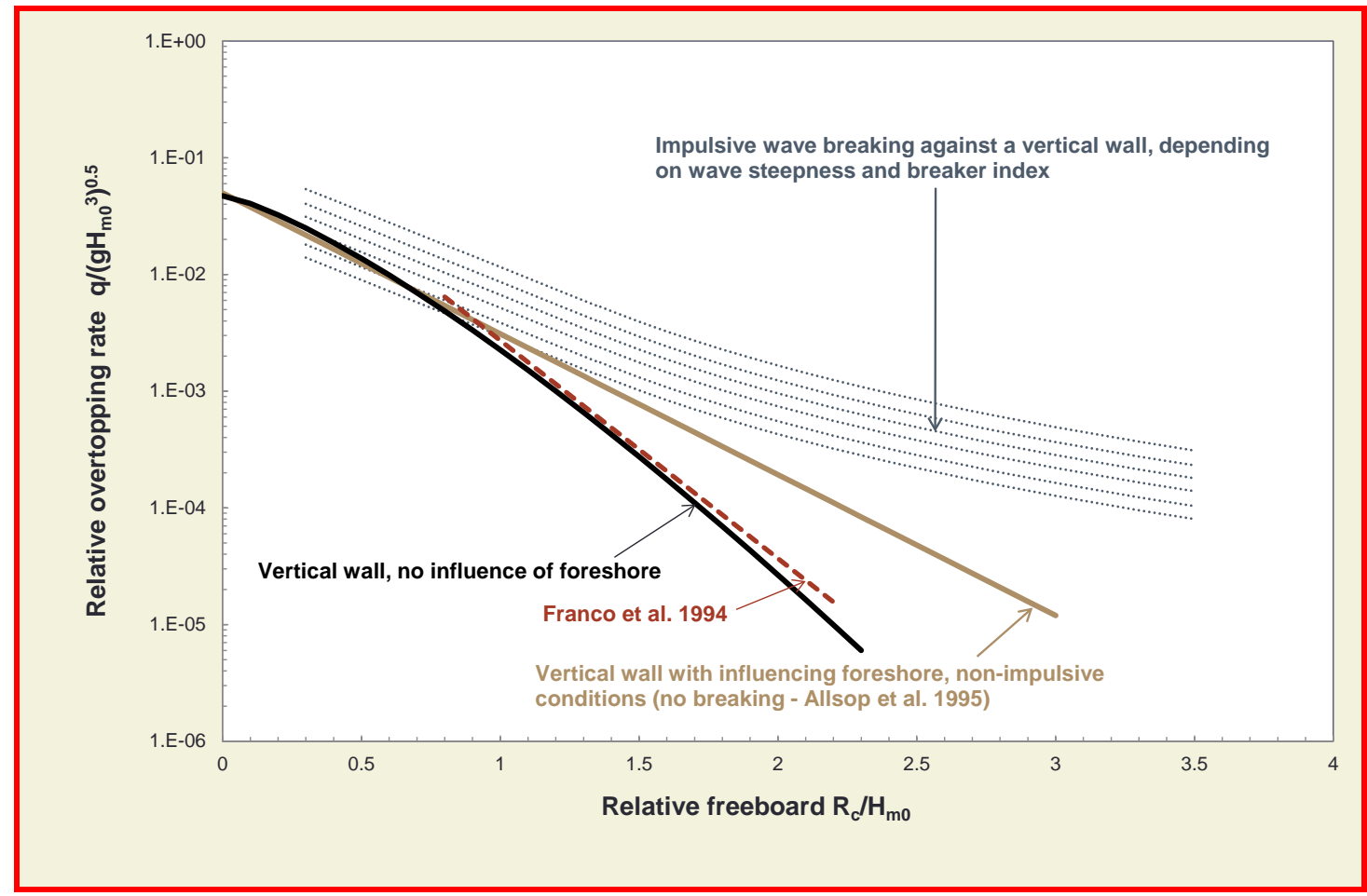

Figure 12. An overview of the regimes of wave overtopping at vertical structures 
For no influencing foreshore:

$$
\frac{q}{\sqrt{g \cdot H_{m 0}^{3}}}=0.047 \cdot \exp \left[-\left(2.35 \frac{R_{C}}{H_{m 0}}\right)^{1.3}\right]
$$

For an influencing foreshore: is there a likelihood of impulsive overtopping conditions?

$$
\begin{aligned}
& \frac{h^{2}}{H_{m 0} L_{m-1,0}}>0.23 \text { treat as non-impulsive conditions } \\
& \frac{h^{2}}{H_{m 0} L_{m-1,0}} \leq 0.23 \quad \text { treat as impulsive conditions }
\end{aligned}
$$

For non-impulsive conditions:

$$
\frac{q}{\sqrt{g H_{m 0}^{3}}}=0.05 \exp \left(-2.78 \frac{R_{c}}{H_{m 0}}\right) \quad \text { Allsop et al. (1995) }
$$

For impulsive conditions:

$$
\begin{array}{ll}
\frac{q}{\sqrt{g H_{m 0}^{3}}}=0.011\left(\frac{H_{m 0}}{h s_{m-1,0}}\right)^{0.5} \exp \left(-2.2 \frac{R_{c}}{H_{m 0}}\right) \text { valid for } 0<\mathrm{R}_{c} / \mathrm{H}_{\mathrm{m} 0}<1.35 \\
\frac{q}{\sqrt{g H_{m 0}^{3}}}=0.0014\left(\frac{H_{m 0}}{h s_{m-1,0}}\right)^{0.5}\left(\frac{R_{c}}{H_{m 0}}\right)^{-3} \quad \text { valid for } \mathrm{R}_{c} / \mathrm{H}_{\mathrm{m} 0} \geq 1.35
\end{array}
$$

\section{REFERENCES}

Allsop, N. W. H., Besley, P. \& Madurini, L. 1995. Overtopping performance of vertical and composite breakwaters, seawalls and low reflection alternatives. Paper 4.7 in MCS Project Final Report, University of Hannover.

EurOtop. 2007. Wave overtopping of sea defences and related structures - Assessment Manual. UK: N.W.H. Allsop, T. Pullen, T. Bruce. NL: J.W. van der Meer. DE: H. Schüttrumpf, A. Kortenhaus. www.overtopping-manual.com.

EurOtop, 2016. Manual on wave overtopping of sea defences and related structures. An overtopping manual largely based on European research, but for worldwide application. Second Edition. Authors: J.W. van der Meer, N.W.H. Allsop, T. Bruce, J. DeRouck, A. Kortenhaus, T. Pullen, H. Schüttrumpf, P. Troch, and B. Zanuttigh. www.overtopping-manual.com.

Franco, L., de Gerloni, M. and Van der Meer, J.W. 1994. Wave overtopping on vertical and composite breakwaters. Proc. 24th Int. Conf. on Coastal Eng, ASCE,1030-1044.

Van der Meer, J.W. and Bruce, T. 2014. New physical insights and design formulas on wave overtopping at sloping and vertical structures. Journal of Waterway, Port, Coastal and Ocean Engineering, 140. DOI 10.1061/(ASCE)WW.1943-5460.0000221.

Van Doorslaer, K., De Rouck, J. and Van der Meer, J.W. 2016. The reduction of wave overtopping by means of a storm wall. Proc. 35th Int. Conf. on Coastal Eng, ASCE.

Victor L. 2012. Optimization of the hydrodynamic performance of overtopping wave energy converters: experimental study of optimal geometry and probability distribution of overtopping volumes. PhD dissertation, Ghent University, Belgium.

Zannutigh, B., Formentin, S. and Van der Meer, J.W. 2016. Update of the Eurotop Neural Network tool: improved prediction of wave overtopping. Proc. 35th Int. Conf. on Coastal Eng, ASCE. 